\title{
Do tropical riparian forests in the Cerrado Biome act as a buffer against the impacts of agriculture and livestock on benthic macroinvertebrate communities?
}

\author{
Renata de Moura Guimarães-Souto1,* (iD, Kátia Gomes Facure² and Giuliano Buzá Jacobucci ${ }^{3}$ \\ 1 Programa de Pós-Graduação em Ecologia e Conservação de Recursos Naturais, Universidade Federal de \\ Uberlândia - UFU. Rua Ceará, s/n, Bloco 2D, Bairro Umuarama, CEP 38408-100, Uberlândia, MG, Brazil. \\ 2 Instituto de Ciências Exatas e Naturais do Pontal, Universidade Federal de Uberlândia - UFU. Rua 20, 1600, \\ Bairro Tupã, CEP 38304-402, Ituiutaba, MG, Brazil. \\ ${ }^{3}$ Instituto de Biologia, Universidade Federal de Uberlândia - UFU. Rua Ceará, s/n, Bloco 2D, Bairro Umuara- \\ ma, CEP 38408-100, Uberlândia, MG, Brazil. \\ * Corresponding author: guimaraesrm@gmail.com
}

Received: 07/11/19 Accepted: 20/07/20

\begin{abstract}
Do tropical riparian forests in the Cerrado Biome act as a buffer against the impacts of agriculture and livestock on benthic macroinvertebrate communities?

Studies on aquatic ecosystems evaluating the effects of land use on benthic macroinvertebrates communities indicate that predictive biological metrics of good environmental quality, such as taxonomic richness and diversity, are lower in streams located in agriculture and livestock areas without a forest buffer when compared to areas of natural vegetation. To test the hypothesis that the structure of benthic macroinvertebrate communities of streams located in impacted areas could be similar to those in intact areas if the riparian vegetation is preserved, we sampled five streams in natural vegetation areas, five in agriculture areas, and three in pasture areas. For the last two stream categories, only locals with preserved riparian vegetation following the Brazilian Forest Code (minimum width of 30-m from each margin) were selected. Land use adjacent to the riparian vegetation was evaluated through satellite images at an $150 \mathrm{~m}$ radius around the upstream limit of each stream. The richness of taxa (families or orders), estimated by rarefaction based on the smallest sample of 7826 individuals, was similar (49-53 taxa) in the three categories of streams, that also did not differ in the community metrics (Simpson Index, Shannon-Winner Diversity Index, \% Chironomidae, Evenness, Richness, and \% EPT) and in the proportion of functional trophic groups. Moreover, the composition of benthic macroinvertebrate communities was also similar among stream categories. These results indicate that the preserved riparian vegetation minimizes the impacts of agricultural and livestock activities on the benthic macroinvertebrate communities in Cerrado biome.
\end{abstract}

Key words: aquatic communities, conservation, land use, permanent preservation areas

\section{RESUMO}

As florestas ripárias no Cerrado protegem as comunidades de macroinvertebrados bentônicos dos impactos do uso da terra pela agricultura e pecuária?

Estudos em ecossistemas aquáticos avaliando os impactos do uso da terra sobre as comunidades de macroinvertebrados bentônicos indicam que as métricas biológicas preditivas de boa qualidade ambiental, como riqueza e diversidade taxonômica, são mais baixas em riachos localizados em áreas de agricultura e pecuária sem a proteção da floresta, quando comparados a áreas de vegetação natural. Para testar a hipótese de que a estrutura das comunidades de macroinvertebrados bentônicos em riachos localizados em áreas impactadas poderia ser semelhante à de áreas íntegras, se a vegetação ripária estiver preservada, foram amostrados cinco riachos localizados em áreas de vegetação natural, cinco em áreas agrícolas e três em áreas de pastagem. Para as duas últimas categorias de riacho, foram selecionados apenas trechos onde a vegetação ripária foi mantida de acordo com o Código Florestal brasileiro (mínimo de $30 \mathrm{~m}$ em cada margem). O uso e a ocupação do solo 
adjacente à vegetação ripária foram avaliados por imagens de satélite em um raio de $150 \mathrm{~m}$ ao redor do limite a montante de cada riacho. A riqueza de táxons (famílias ou ordens) estimada por rarefação com base na menor amostra de 7826 indivíduos foi semelhante (49-53 táxons) nas três categorias de riacho, que também não diferiram nas métricas da comunidade (Índice de Simpson, Índice de Diversidade de Shannon-Winner \% Chironomidae, Equidade, Riqueza e \% EPT) e na proporção dos grupos tróficos. Além disso, a composição da comunidade de macroinvertebrados bentônicos também foi similar nas categorias de riacho. Esses resultados indicam que a vegetação ripária preservada contribui para minimizar o impacto das atividades de pastagem e agricultura sobre as comunidades de macroinvertebrados bentônicos no bioma Cerrado.

Palavras chave: comunidades aquáticas, conservação, uso da terra, áreas de preservação permanente

\section{INTRODUCTION}

The Cerrado is the species-richest savannah in the world and the second largest biome in South America, occupying $22 \%$ of Brazil's territory. It includes the headwaters of the three main hydrographic basins of South America, Amazon-Tocantins, São Francisco, and Prata river basins. Because of the high biodiversity and strong environmental pressures (Myers et al., 2000; Françoso et al., 2020), the biome is recognized as a biodiversity hotspot, i.e., a priority conservation area. Compared to other biodiversity hotspots on the planet, the Cerrado is the one with the lowest percentage of areas of integral protection, with $\sim 8 \%$ of its territory legally protected within conservation units (MMA, 2019).

The conversion of the Cerrado to farmlands and pastures and the pollution/eutrophication can negatively affect many species in both terrestrial and aquatic environments (Klink \& Machado, 2005). For aquatic organisms, the decrease in species diversity has been attributed mainly to the use of fertilizers and metal-containing agrochemicals, and the deforestation of riparian vegetation (Corbi et al., 2010). Livestock grazing also contributes to the loss of riparian forests leading to a reduction of allochthonous organic matter input, weed invasion, soil compaction, and increased runoff, erosion, solar radiation, and algal growth (Fleischner, 1994; Belsky et al., 1999, Kok et al., 2020).

Environmental degradation frequently results in biotic homogenization namely the taxonomic and functional simplification of the communities (McKinney \& Lockwood, 1999; Olden \& Rooney, 2006), resulting from a loss of species and changes in their abundance with reductions in local diversity (Gibson et al., 2011; Newbold et al., 2015; Zhang et al., 2018) and $\beta$-diversity (Whittaker, 1972; Karp et al., 2012). The impoverished subset of taxa usually has relatively high dispersion abilities and generalist feeding habits (Vellend et al., 2007; Karp et al., 2012).

In trophic webs of aquatic environments benthic macroinvertebrates constitute an essential ecological group, influencing energy flow and nutrient cycling (Whiles \& Wallace, 1997). They are widely used in biomonitoring providing reliable information on water quality since they are good indicators of environmental conditions (Bonada et al., 2006; Woodcock \& Huryn, 2007; Patang et al., 2018).

Studies on aquatic ecosystems in temperate and tropical regions evaluating the effect of land use on benthic macroinvertebrate communities indicate that richness and diversity are significantly lower in streams flowing through areas impacted by agriculture and livestock production. These streams have a depletion in benthic communities, with a predominance of tolerant macroinvertebrate taxa. In these studies, the impoverishment of the benthic community have been related to the deteriorated condition or absence of riparian vegetation (Townsend et al., 2003; Hepp et al., 2010; Hepp et al., 2016, Siegloch et al., 2014). However, at least in temperate ecosystems, it has been demonstrated that the effects of land use do not result in significant changes to aquatic communities where riparian vegetation remains intact (Sweeney, 1993; Silla, 2005; Yirigui, 2019). In Brazil, and several other Neotropical developing countries, with a growing expansion of agricultural and livestock activities, we believe that this would be a very important ecological issue to be evaluated. 
Considering the ecological services offered by riparian forests, such as maintaining water quality, promoting riverbank stability and thermal water balance, functioning as ecological corridors, and providing food resource for fishes and invertebrates (Naiman \& Décamps, 1997; Attanasio et al., 2012, Chellaiah \& Catherine, 2018), we hypothesized that the structure of benthic macroinvertebrate communities of streams located in agriculture and pasture areas could be similar to those streams in natural areas if the riparian vegetation is well-preserved.

This type of forest ecosystem should act as a buffer against the possible impacts of the anthropic activities mentioned and maintain sufficient input of organic matter into benthic aquatic communities. The present study aimed to compare the community structure of benthic macroinvertebrates among streams with intact riparian vegetation located in three different categories of land use: natural vegetation (control), agriculture and pasture.

\section{METHODOLOGY}

\section{Study site}

The Cerrado region of the Triângulo Mineiro (state of Minas Gerais) and in the south of the state of Goiás, in southeastern and central Brazil, harbors watersheds consisting of numerous streams of diverse orders of magnitude. The Uberabinha River basin includes streams in agricultural and pasture areas with restored riparian forests by the conservation efforts of a conservation project (Buriti program). This project started in 2008 with the implementation of permanent preservation areas (PPAs) in compliance with the Brazilian Forest Code, which establishes that in all streams and rivers $<10$-wide, a 30-m wide riparian forest strip must be preserved on each margin as a PPA (CONAMA, 2002; Brasil, 2012).

An adaptation of these PPAs to the Brazilian Forest Code was made possible through environmental education actions offered to farmers and,

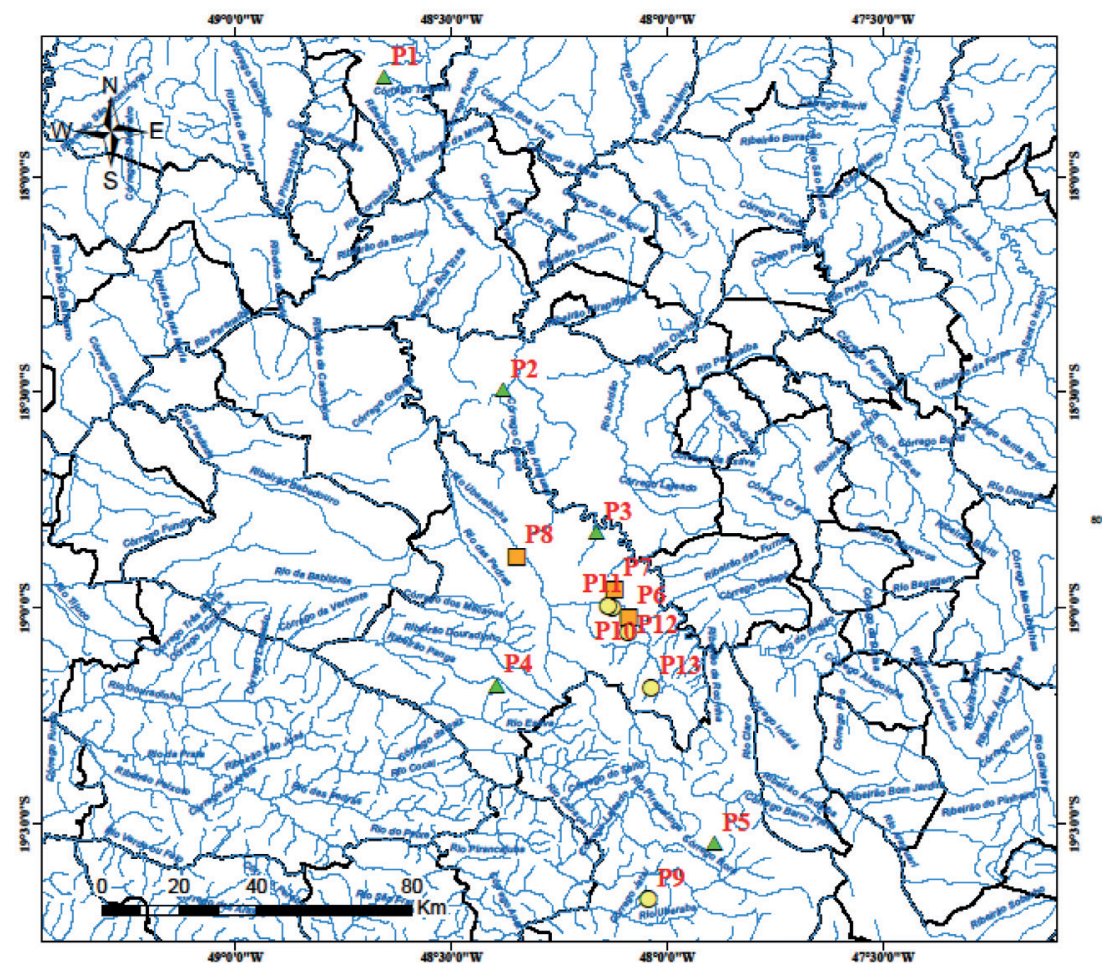

\section{Localization of} Samplig Sites

Legend

- Agricultural Areas

$\Delta \quad$ Natural Areas

$\square \quad$ Pasture Areas

whor- Drainage

Municipal Limits

UTM Coordinate System
Datum SIRGAS $200022 \mathrm{~S}$
Sources: Google Earth, IBGE, ANA September, 2018
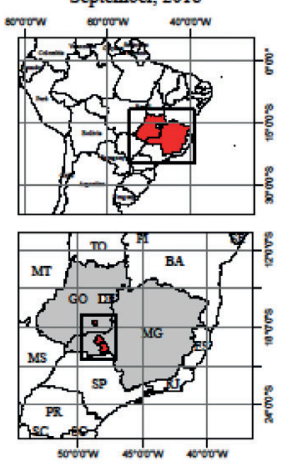

Figure 1. Location of sampling sites. Localização dos pontos amostrais. 
Table 1. Geographic location of sampling points and river hierarchy scale defined by Horton (1945) and modified by Strahler in 1952. Localização geográfica dos pontos de amostragem e escala hierárquica dos rios definida por Horton (1945) e modificada por Strahler em 1952.

\begin{tabular}{|c|c|c|c|c|}
\hline & Streams & River hierarchy & Average width (m) & Average depth (m) \\
\hline \multirow{5}{*}{ 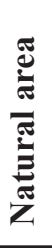 } & Cascatinha (P1) & $1^{\mathrm{a}}$ order & 1.37 & 0.39 \\
\hline & Água Fria (P2) & $3^{\mathrm{a}}$ order & 3.4 & 0.29 \\
\hline & Marimbondo (P3) & $3^{\mathrm{a}}$ order & 3.2 & 0.08 \\
\hline & Panga (P4) & $1^{\mathrm{a}}$ order & 2.0 & 0.6 \\
\hline & Uberaba (P5) & $1^{\mathrm{a}}$ order & 1.59 & 0.21 \\
\hline \multirow{3}{*}{ 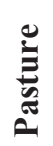 } & Corredeira (P6) & $1^{\mathrm{a}}$ order & 1.3 & 0.15 \\
\hline & Cabeceira do Letreiro (P7) & $1^{\mathrm{a}}$ order & 1.0 & 0.27 \\
\hline & Capim Branco (P8) & $1^{\mathrm{a}}$ order & 2.4 & 0.12 \\
\hline \multirow{5}{*}{ 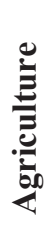 } & Sucupira Cassu (P9) & $1^{\mathrm{a}}$ order & 2.03 & 0.24 \\
\hline & Bugre (P10) & $1^{\mathrm{a}}$ order & 2.5 & 0.25 \\
\hline & Fortaleza (P11) & $1^{\mathrm{a}}$ order & 1.10 & 0.30 \\
\hline & Omar Mamede (P12) & $1^{\mathrm{a}}$ order & 0.90 & 0.17 \\
\hline & Fortaleza II (P13) & $1^{\mathrm{a}}$ order & 1.5 & 0.21 \\
\hline
\end{tabular}

as a second step, with the delimitation of PPAs using wire fences to avoid cattle trampling on riverside vegetation and revegetation with native plants when necessary. Until the late 1960 s, the Cerrado region was marked by extensive cattle ranching, and in the late 1970s, soybean cultivation was introduced. The flat topography and easy access to limestone deposits in the area were favorable to agricultural expansion and the intensive use of agrochemicals. Tax incentives also stimulated the plantation of pine and eucalyptus trees (Schneider, 1996) and besides that, since 1999 large areas of the region have been dedicated to the cultivation of sugarcane (Brito \& Dos Reis, 2012).

Thirteen low order streams of the Paranaíba River watershed in the Triângulo Mineiro region of Minas Gerais and in southern Goiás were selected based on land use adjacent to streams (Fig. 1). The local climate is a tropical Aw megathermal type, according to the Köppen classification, with summer rains from October to March and winter drought from April to September. Five streams were located in areas of natural vegetation, five in agriculture, and three in pasture (Table 1). For the last two stream categories, only locals with preserved riparian vegetation following the Brazilian Forest Code (minimum width of 30-m from each margin) were selected. Streams of the natural vegetation category are located inside conservation units: two state parks (Cascatinha and Marimbondo), one ecological station (Panga), and two private natural reserves (Água Fria and Uberaba).

The land use adjacent to the riparian vegetation associated with streams was evaluated through satellite images obtained in May 2017 from all locations. The percentages of natural vegetation, pasture, and agriculture cover were determined for an 150-m radius area around the upstream limit of each location (Figs. S1 to S13, available at http://www.limnetica.net/en/limnetica) (Carvalho et al., 2015) using Google Earth.

\section{Data collection and processing}

A continuous segment proportional to the width of the stream (defined as 40 times the average width of the stream) in each watercourse was sampled for benthic macroinvertebrates. This segment was subdivided into five equal sections, and five sub-samples (one per section) of benthic 
macroinvertebrates were collected from each site (Castro et al., 2016).

The collection was performed with a ' $D$ ' net (30 cm aperture, $500 \mathrm{~mm}$ mesh), following a systematic zigzag pattern across the defined segments. Five sample units per stream $\left(0.09 \mathrm{~m}^{2}\right.$ each) were taken, one per section, totaling $0.45 \mathrm{~m}^{2}$ per site.

Samples were fixed in $70 \%$ alcohol in the field, and then transported to the laboratory for screening and invertebrate identification to family level (Merritt \& Cummins, 1996; Mugnai et al., 2010 keys). The following metrics were used to represent the benthic invertebrate communities: richness; Shannon-Whinner Diversity Index; \% Ephemeroptera, Plecoptera, and Trichoptera (EPT); \% Chironomidae; evenness; and Simpson Dominance Index. These indices are frequently used in environmental quality studies (Boyer-Rechlin et al., 2016; Gerth et al., 2017; Leslie \& Lamp, 2017).
Invertebrates were classified into feeding functional groups (Tables S1, S2, and S3, available at http://www.limnetica.net/en/limnetica): collector gatherers, predators, collector-filters, shredders, and scrapers (Merritt \& Cummins, 1996; Cummins et al., 2005). A sixth category was considered for taxa that use mixed feeding strategies, which are then considered generalists.

Stream depth and width were measured and the following physical and chemical parameters of the water were measured with multi-parameter equipment (Horiba U-50 model): temperature, $\mathrm{pH}$, conductivity, total dissolved solids, turbidity, and dissolved oxygen. Sampling was carried out during the dry season between late June and early October 2017.

\section{Data analysis}

Physicochemical and biological (benthic macroinvertebrates metrics and abundance of

Table 2. Physical and chemical parameters of the water of streams of different categories of land use. Parâmetros fisicos e quimicos da água de riachos de diferentes categorias de uso do solo.

\begin{tabular}{|c|c|c|c|c|c|c|c|}
\hline & Streams & $\begin{array}{c}\text { Temperature } \\
\left({ }^{\circ} \mathrm{C}\right)\end{array}$ & pH & $\begin{array}{c}\text { Turbidity } \\
\text { (NTU) }\end{array}$ & $\begin{array}{l}\text { Conductivity } \\
(\mathrm{mS} / \mathrm{cm})\end{array}$ & $\begin{array}{c}\text { Dissolved } \\
\text { oxygen } \\
(\mathrm{mg} / \mathrm{L})\end{array}$ & $\begin{array}{c}\text { Total } \\
\text { dissolved } \\
\text { solids (g/L) }\end{array}$ \\
\hline \multirow{5}{*}{ 苞 } & PESCAN & 21.98 & 8.25 & 0.00 & 0.007 & 9.23 & 0.004 \\
\hline & Água Fria & 16.30 & 6.74 & 11.40 & 0.015 & 11.14 & 0.001 \\
\hline & Marimbondo & 20.65 & 7.94 & 17.60 & 0.043 & 10.57 & 0.028 \\
\hline & Panga & 18.36 & 6.43 & 11.90 & 0.005 & 9.88 & 0.004 \\
\hline & Uberaba & 19.65 & 8.26 & 8.80 & 0.004 & 8.37 & 0.03 \\
\hline Mean & & 19.39 & 7.52 & 9.94 & 0.01 & 9.84 & 0.01 \\
\hline \multirow{3}{*}{ 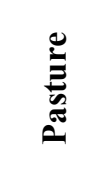 } & Corredeira & 14.62 & 6.24 & 28.50 & 0.006 & 11.12 & 0.004 \\
\hline & $\begin{array}{l}\text { Cabeceira do } \\
\text { Letreiro }\end{array}$ & 17.26 & 6.37 & 110.0 & 0.011 & 8.75 & 0.007 \\
\hline & Capim Branco & 20.49 & 6.34 & 60.60 & 0.037 & 9.64 & 0.025 \\
\hline Mean & & 17.46 & 6.32 & 66.37 & 0.02 & 9.84 & 0.01 \\
\hline \multirow{5}{*}{ 畩 } & Sucupira Cassu & 18.35 & 6.76 & 20.10 & 0.03 & 9.97 & 0.019 \\
\hline & Bugre & 15.50 & 5.51 & 20.00 & 0.008 & 10.63 & 0.005 \\
\hline & Fortaleza & 19.44 & 5.52 & 333.00 & 0.004 & 9.42 & 0.003 \\
\hline & Omar Mamede & 19.44 & 4,40 & 11.70 & 0.004 & 9.42 & 0.003 \\
\hline & Fortaleza II & 17.72 & 5.57 & 12.20 & 0.003 & 10.20 & 0.002 \\
\hline Mean & & 18.09 & 5.55 & 79.40 & 0.01 & 9.93 & 0.01 \\
\hline
\end{tabular}


individuals by trophic groups) measures were compared among streams of the three categories of land use by performing analysis of variance (one-way ANOVA), considering each stream as a sampling unit, resulting from the sum of the five sub-samples within each one of them. Residual plots were used to detect the violation of assumptions in ANOVA, such as variance heterogeneity, nonnormality of errors, and the presence of outliers. If residuals were not normally distributed and/or if variances were not homogeneous among groups, non-parametric test Kruskal-Wallis was used instead.

Abundances of benthic macroinvertebrate taxa were compared among stream categories by estimating the size-weighted Horn (1966) similarity index. The standard error for each estimate was obtained using a bootstrap method based on 200 replications along $95 \%$ confidence intervals. To classify taxa as rare, the criterion established by Silla (2005) was used as a reference. Rarefaction curves, as a function of the number of individuals, were used for comparisons of estimated richness among streams from natural, agriculture, and pasture areas.

To test for differences among the three categories of streams regarding the structure of macroinvertebrate communities, a Bray-Curtis similarity matrix, based on log-transformed [log $(\mathrm{X}+1)$ ] abundance data, was submitted to permutational multivariate variance analysis (PERMANOVA). To visualize multivariate community patterns, the same similarity matrix was represented in a cluster analysis using the average linkage method.

Statistical analyses were conducted using $\mathrm{R}$ version 3.3.2 (R Core Team, 2019) and the packages "pgirmess" (Giraudoux, 2018), "SpadeR" (Chao et al., 2016), "vegan" (Oksanen et al., 2013) and "BiodiversityR" (Kindt \& Coe, 2005).

\section{RESULTS}

\section{Physical and chemical parameters of water}

Streams from the three categories of land use did not differ regarding the following physicochemical parameters: temperature (ANOVA $F_{2,10}=$ $0.885, p=0.443$ ), conductivity (Kruskal-Wallis $\left.\chi^{2}=1.697, d f=2, p=0.428\right)$, dissolved oxygen (Kruskal-Wallis $\chi^{2}=0.026, d f=2, p=0.987$ ) and total dissolved solids (Kruskal-Wallis $\chi^{2}=1.533$, $d f=2, p=0.465$ ) (Table 2 ). The $\mathrm{pH}$ mean value was lower in streams from agricultural than in natural areas (ANOVA $F_{2,10}=8.418, p=0.007$ followed by Tukey test) and turbidity was lower in streams from natural than pasture areas (Kruskal-Wallis $\chi^{2}=7.305, d f=2, p=0.026$ followed by post hoc test).

\section{Benthic Macroinvertebrates}

The community of benthic macroinvertebrates was quite diverse and abundant (Tables S1, S2, and S3). A total of 67 taxa were observed in the three stream categories. Sample size (and number of observed taxa) was 11647 (56 taxa) in the five streams from natural areas, 9564 (56 taxa) in the five streams from agricultural areas, and 7826 (49 taxa) in the three streams from pastures. Number of observed shared taxa in the three stream categories was 43 .

Table 3. Comparisons of the average richness by sample, observed total richness and estimated total richness for the three categories of land use. Comparação da riqueza média por amostra, riqueza total observada e riqueza total estimada para as três categorias de uso do solo.

\begin{tabular}{lccccc}
\hline & $\mathbf{n}$ & $\begin{array}{c}\text { Total } \\
\text { abundance }\end{array}$ & $\begin{array}{c}\text { Average richness by } \\
\text { sample (mín.-máx.) }\end{array}$ & $\begin{array}{c}\text { Observed } \\
\text { total richness }\end{array}$ & $\begin{array}{c}\text { Estimated total } \\
\text { richness }\end{array}$ \\
\hline Agriculture & 5 & 9564 & $30.6(25-41)$ & 56 & 53.9 \\
Natural Area & 5 & 11647 & $29.0(17-35)$ & 56 & 52.8 \\
Pasture & 3 & 7826 & $33.0(30-38)$ & 49 & 49.0 \\
\hline
\end{tabular}




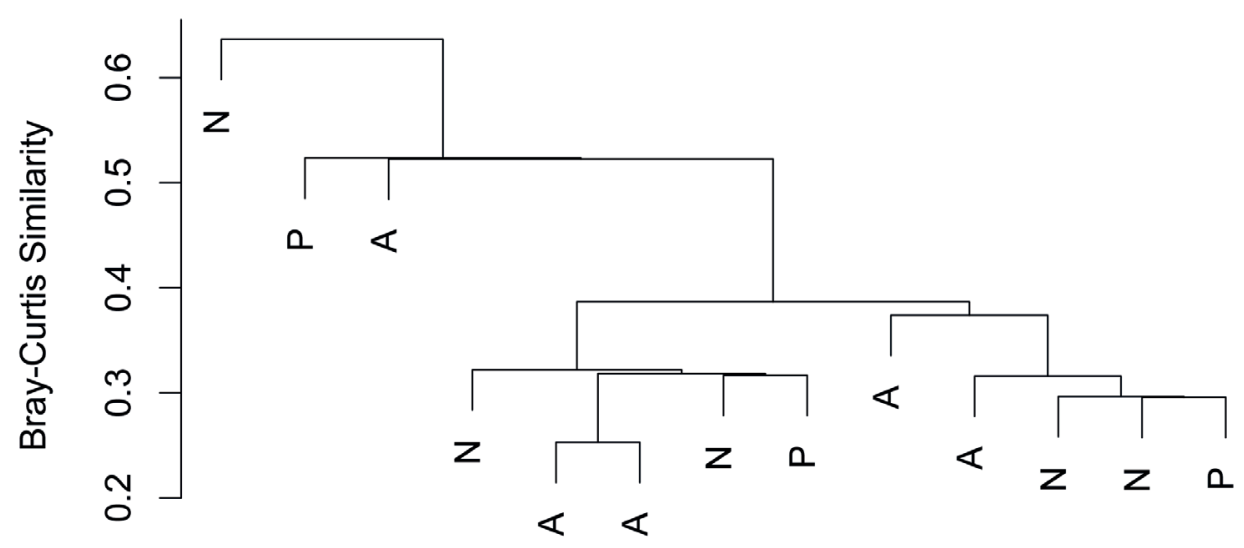

Figure 2. Cluster analysis comparing the benthic macroinvertebrate communities among the three types of land use. Análise de agrupamento comparando as comunidades de macroinvertebrados bentônicos entre os três tipos de uso da terra.

Comparisons of the relative abundances (size-weighted Horn similarity index) of taxa, with bootstraps of 200 replications, provided an average pairwise similarity of 0.8435 . The mean $\pm \mathrm{SE}$ similarity index between the natural and pasture streams was $0.754 \pm 0.005$ (95 \% CI 0.746-0.767), between natural and agriculture was $0.894 \pm 0.004$ (95\% CI 0.887-0.902), and between agriculture and pasture was $0.846 \pm$ 0.007 (95\% CI 0.832-0.861).

Twenty-three macroinvertebrate taxa were considered rare, occurring in fewer than four of the 13 streams. Six families - Elmidae, Chironomidae, Ceratopogonidae, Baetidae, Hydropsychidae, and Oligochaeta - were particularly common, occurring in all sampled streams.

The taxonomic richness estimated by rarefaction based on the smallest sample of 7826 individuals was similar in the three categories of streams, varying from 49 to 53 taxa (Table 3 ). Moreover, no significant differences were found among stream categories for Simpson diversity $\left(F_{2,10}=0.159, p=0.855\right)$, Shannon-Winner diversity $\left(F_{2,10}=0.357, p=0.708\right)$, \% Chironomidae (Kruskal-Wallis $\chi^{2}=0.422, p=0.810$ ), evenness $\left(F_{2,10}=0.315, p=0.736\right)$, richness $\left(F_{2,10}=0.347 ; p=0.715\right)$, and $\% \operatorname{EPT}\left(F_{2,10}=\right.$ $0.023, p=0.978)$.

The PERMANOVA based on the Bray-Curtis similarity matrix and 9999 permutations did not find significant differences among the stream

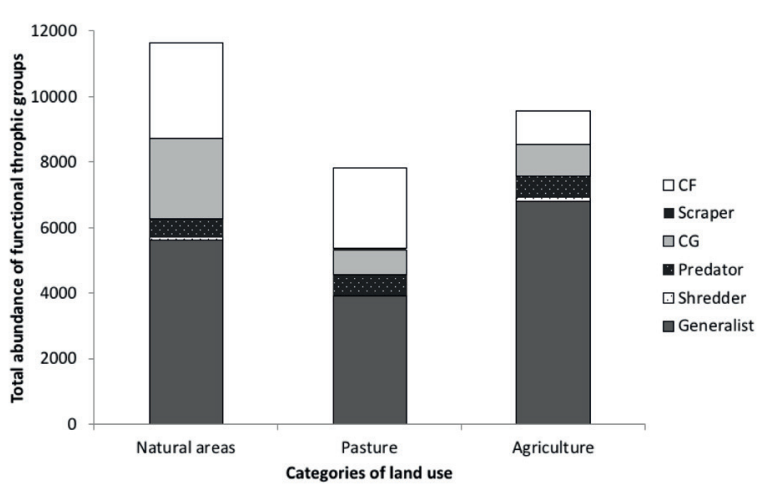

Figure 3. Proportion of the functional trophic groups of the community of benthic macroinvertebrates in the three categories of streams. Proporção dos grupos tróficos funcionais da comunidade de macroinvertebrados bentônicos nas três categorias de riachos.

categories regarding the composition of macroinvertebrate communities (Pseudo- $F_{2,10}=1.013$; $\left.R^{2}=0.168 ; p=0.459\right)$. The same results were showed in the cluster analysis that did not separated stream categories in distinct groups (Fig. 2).

Stream categories did not differ in the abundance of individuals by functional feeding groups (generalists: $F_{2,10}=0.073, p=0.930$; shredders: $F_{2,10}=1.268, p=0.325$; predators: $F_{2,10}=0.598$, $p=0.569$; collector gatherers: Kruskal-Wallis $\chi^{2}=0.563, d f=2, p=0.755$; scrapers: Kruskal-Wallis $\chi^{2}=2.431, d f=2, p=0.297$; and 
filters: Kruskal-Wallis $\chi^{2}=1.139, d f=2, p=$ 0.566 ), with generalists occurring at higher abundance in all streams sampled (Fig. 3).

\section{DISCUSSION}

The impact of agriculture and pasture on the benthic invertebrate communities has been widely studied in both tropical (Hepp \& Santos, 2009; Hepp et al., 2010; Siegloch et al., 2014, Hardie \& Bobbi, 2017) and temperate regions (Townsend et al., 2003; Jun et al., 2011; Virbickas et al., 2011; Gerth et al., 2017). All these studies showed that land-use negatively affects macroinvertebrate communities in streams lacking a forest buffer (riparian forest).

In the present study, the presence of a well-preserved riparian vegetation apparently protected aquatic communities from agriculture and livestock impacts since benthic macroinvertebrates communities in streams from these impacted areas were similar to those found in streams from natural areas (control). This finding corroborates the data previously published by Silla (2005), who found no differences between benthic macroinvertebrate communities in streams with preserved riparian forest and pristine areas in Australia.

Riparian forests can protect aquatic communities by reducing the entry of pesticides, fertilizers, and fine sediments into water bodies (Shortle et al., 2001; Dosskey et al., 2010). In addition, riparian forests represent an important source of shelter and food for the aquatic community through the transfer of allochthonous material to streams (König et al., 2014). The presence or absence of riparian vegetation also affects other environmental variables, such as water temperature and substrate quantity/quality (Oliveira-Junior et al., 2017). The importance of riparian forests is crucial for some groups, such as Odonata, being more important to determine their assemblage structure than water quality (Carvalho et al., 2013; Oliveira-Junior et al., 2017).

Our results indicate that streams of the three land-use categories have good water quality based on the physical and chemical parameters analyzed. Although inserted in pasture or agricultural areas, the riparian vegetation of these areas can act as a buffer against possible environmental impacts caused by anthropic activities. These findings are corroborated by Anbumozhi et al. (2005), who showed the positive impact of riparian zones on the reduced influence of nutrients and agricultural chemicals on surface waters.

The lower $\mathrm{pH}$ values in streams from agricultural areas (Omar Mamede, Fortaleza and Bugre streams) should probably be due to the hydromorphic soils in the area, which have black colors, low drainage and are strongly acidic, with $\mathrm{pH}$ between 4.0 and 5.4 (Melo, 2008; Moraes et al., 2010). The low values of electrical conductivity in all streams sampled suggest little anthropic influence on watercourses, since this parameter represents an indirect measure of the concentration of pollutants, with general levels higher than $100 \mu \mathrm{S} / \mathrm{cm}$ indicating environmental impact (Fravet \& Cruz, 2007).

The high abundance of Chironomidae in all streams refers to the high adaptive capacity of the group (Trivinho-Strixino \& Strixino, 1995), which is dominant in many benthic macroinvertebrate communities. In this study, chironomids constituted the main component of the generalist category, and for this reason, they made the trophic group more representative in all streams.

The equitable occurrence of EPT, indicated by the absence of significant differences in the abundance of the group among categories of land use in all streams, indicates good environmental conditions, mainly due to the presence of Gripopterygidae (Plecoptera), Odontoceridae (Trichoptera), and Helycopsychidae (Trichoptera). These EPT families are among the most sensitive to environmental impacts (Zamora-Muñoz \& Alba-Tercedor, 1996; Junqueira \& Campos, 1998). Although the occurrence of Gripopterygidae and Helycopsychidae was restricted (occurring in only one and two watercourses, respectively), Odontoceridae were quite frequent, and representatives of this family were found in 12 of the 13 streams sampled, indicating that these aquatic ecosystems have appropriate biotic and abiotic conditions for their development.

The highest abundance of Perlidae (Plecoptera) occurred among agricultural streams (48\%). As the group is also sensitive to pollution (Zamora-Muñoz \& Alba-Tercedor, 1996; Junqueira \& 
Campos, 1998) they suggest good environmental conditions.

Pasture and agricultural streams had a large proportion of rare taxa $(33 \%$ and $44 \%$, respectively). The family Philopotamidae, for example, was restricted to only one of the streams in the pasture category and seems to colonize preferably small streams (Nogueira et al., 2011; Bishop, 2012; Carvalho, 2014). This family is considered sensitive to pollution (Alba-Tercedor, 2000).

The evaluation of functional feeding groups is an indirect tool for environmental quality assessment since it is understood that an imbalance in food dynamics will result in a change in the composition and abundance of functional feeding groups, thereby reflecting habitat conditions (UWADIAE, 2010). Trophic groups did not differ among land categories. It is common to find a decrease in the percentage of shredders in impacted sites (Hepp et al., 2016) because of the reduction of allochthonous material supply, where riparian vegetation is lost (Kerans \& Karr, 1994; Buss et al., 2002). This was not found in our study, reflecting similar trophic structures between streams and thus emphasizing the ecological role of riparian forests.

Based on the concept that riparian forests are essential for maintaining the balance of aquatic ecosystems, the suitability of the Brazilian law is perceived by establishing the maintenance of at least $30 \mathrm{~m}$ of riparian vegetation for watercourses up to $10 \mathrm{~m}$ wide, or in the case of areas with riparian forest already suppressed, the owner or occupant is supposed to promote the restoration of the vegetation (Brasil, 2012). In this study, the role of PPAs acting as a buffer against possible effects of agriculture and livestock is clear, allowing the occurrence of a diverse and abundant community of benthic macroinvertebrates.

These findings are important in an environmental context for countries such as Brazil where livestock and agriculture activities are extensively exploited and unfortunately there is no strong culture related to environmental preservation. Riparian forests are often economically targeted by farmers because of the quality of forage they produce and as water supply sources. As a result, many riparian habitats are subject to overgrazing in several regions of Brazil.
Outcomes of our results bring us the idea of the sustainable use of natural resources, understanding in this case that it is possible to develop livestock and agriculture activities adjacent to watercourses, but it is important to maintain riparian vegetation areas. These areas are essential for the conservation of aquatic biodiversity and other environmental services, such as maintaining the thermal balance of aquatic and terrestrial ecosystems, soil conservation, and terrestrial biodiversity.

\section{ACKNOWLEDGEMENTS}

We thank the essential logistical support from DMAE / Buriti Program, the Post-Doctoral fellowship granted from Capes / CNPq-PELD Process Number: 441225/2016-0 and the managers of the conservation units where we collected the field data for this study. We would also like to thank the rural landowners who allowed the research to be carried out in the water courses inserted in their farms.

\section{REFERENCES}

ANBUMOZHI, V., J. RADHAKRISHNAN \& E. YAMAJI. 2005. Impact of riparian buffer zones on water quality and associated management considerations. Ecological Engineering, 24(5): 517-523. DOI: 10.1016/j.ecoleng. 2004.01 .007

ATTANASIO, C. M., S. GANDOLFI, M. J. B. ZAKIA, J. C. T. VENIZIANI JUNIOR \& W. P. LIMA. 2012. A importância das áreas ripárias para a sustentabilidade hidrológica do uso da terra em microbacias hidrográficas. Bragantia, 71(4): 493-501. DOI: 10.1590/ S0006-87052013005000001

BELSKY, A. J., A. MATZKE \& S. USELMAN. 1999. Survey of livestock influences on stream and riparian ecosystems in the western United States. Journal of Soil and Water Conservation, 54 (1): 419-431.

BISHOP, J. 2012. Limnology of a small Malayan River Sungai Gombak. 1st Ed. Springer Science e Business Media. USA).

BONADA, N., N. PRAT, V. H. RESH \& B. STATZNER. 2006. Developments in aquatic 
insect biomonitoring: A comparative analysis of recent approaches. Annual Review of Entomology, 51: 495-523. DOI: 10.1146/annurev. ento.51.110104.151124

BOYER-RECHLIN, N. , G. L. BRULAND \& M. A. RECHLIN. 2016. The effects of agricultural land use on benthic macroinvertebrate communities and the applicability of family level bioassessment metrics in southern Illinois headwater streams. Transactions of the Illinois State Academy of Science, 518: 49-56. BRASIL. 2012. Lei Federal $n^{\circ} 12.651$ (Novo Código Florestal Brasileiro), de 25 de maio de 2012, que dispõe sobre a proteção da vegetação nativa; altera as Leis $n^{\circ} \mathrm{s} 6.938$, de 31 de agosto de 1981, 9.393, de 19 de dezembro de 1996, e 11.428 , de 22 de dezembro de 2006; revoga as Leis $n^{\circ} \mathrm{s} 4.771$, de 15 de setembro de 1965, e 7.754, de 14 de abril de 1989 e a Medida Provisória $\mathrm{n}^{\mathrm{o}}$ 2.166- 67, de 24 de agosto de 2001; e dá outras providências. Diário Oficial da União - Seção I (102), pp. 1-8.

BRITO, J. L. S. \& L. N. G. DOS REIS. 2012. Mapeamento das áreas de conversão do uso da terra para cana-de-açúcar na mesorregião do Triângulo Mineiro/Alto Paranaíba-MG por meio de imagens TM/LANDSAT. Revista Caminhos de Geografia, 13(41): 170-186.

BUSS, D. F., D. F. BAPTISTA, M. P. SILVEIRA, J. L. NESSIMIAN \& L. F. M. DORVILLÉ. 2002. Influence of water chemistry and environmental degradation on macroinvertebrate assemblages in a river basin in south-east Brazil. Hydrobiologia, 481(1-3): 25-136. DOI: 10.1023/A:1021281508709

CARVALHO, F. G. D., N. S. PINTO, J. M. B. D OLIVEIRA JÚNIOR \& JUEN, L. 2013. Effects of marginal vegetation removal on Odonata communities. Acta Limnologica Brasiliensia, 25(1): 10-18.

CARVALHO, D. R., D. CASTRO, M. CALLISTO, M. Z. MOREIRA \& P. S. POMPEU. 2015. Isotopic variation in five species of stream fishes under the influence of different land uses. Journal of Fish Biology, 87(3): 559-578. DOI: 10.1111/jfb.12734

CARVALHO, L. K. de. 2014. Drift de macroinvertebrados em riachos de cabeceira (cidade, Brasil). Dissertação de Mestrado. Universi- dade Estadual da Paraíba, Centro de Ciências Biológicas e da Saúde, Campina Grande, Paraíba, Brasil.

CASTRO, D. M. P. de, D. R. CARVALHO, P. S. POMPEU, M. Z. MOREIRA, G. B. NARDOTO \& M. CALLISTO. 2016. Land use influences niche size and the assimilation of resources by benthic macroinvertebrates in tropical headwater streams. PLoS ONE, 11(3): 1-19. DOI: 10.1371/journal.pone.0150527

CHAO A., K. H. MA, T. C. HSIEH \& C. CHIU. 2016. SpadeR: species-richness prediction and diversity estimation with $R$. $\mathrm{R}$ package version 0.1.1.

CHELLAIAH, D. \& C. M. YULE. 2018. Effect of riparian management on stream morphometry and water quality in oil palm plantations in Borne. Limnologica, 69: 72-80. DOI: 10.1016/j.limno.2017.11.007

CONAMA - Conselho Nacional do Meio Ambiente. 2002. Resolução $n^{\circ} 303$, de 20 de março de 2002, que dispõe sobre 556 parâmetros, definições e limites de Áreas de Preservação Permanente. Brasília. Diário Oficial da União - Seção I (090), p. 068.

CORBI, J. J., C. G. FROEHLICH, S. T. STRIXINO \& A. DOS SANTOS. 2010. Bioaccumulation of metals in aquatic insects of streams located in areas with sugar cane cultivation. Química Nova, 33(3): 644-648. DOI: 10.1590/S0100-40422010000300030

CUMMINS, K. W, R. W. MERRITT \& P. ANDRADE. 2005. The use of invertebrate functional groups to characterize ecosystem attributes in selected streams and rivers in southeast Brazil. Studies on the Neotropical Fauna and Environment, 40(1): 69-89. DOI: 10.1080/01650520400025720

DOSSKEY, M. G., P. VIDON, N. P. GURWICK, C. J. ALLAN, T.P DUVAL \&, R. LOWRANCE. 2010. The role of riparian vegetation in protecting and improving chemical water quality in streams. Journal of the American Water Resources Association, 46(2):261 277. DOI: $10.1111 / \mathrm{j} .1752-1688.2010 .00419 . x$

FLEISCHNER, T. L. 1994. Ecological costs of livestock grazing in western North America. Conservation Biology, 8(3): 629-644. DOI: 10.1046/j.1523-1739.1994.08030629.x 
FRANÇOSO, R. D., K. G. DEXTER, R. B. MACHADO, R. T. PENNINGTON, J. R. R. PINTO, R. A. BRANDÃO, J. A. RATTER. 2020. Delimiting floristic biogeographic districts in the Cerrado and assessing their conservation status. Biodiversity and Conservation 29: 1477-1500. DOI: 10.1007/s10531019-01819-3

FRAVET, A M. M. F. \& R. L. CRUZ. 2007. Qualidade da água utilizada para irrigação de hortaliças na região de Botucatu - SP. Irriga, Botucatu, 12(2): 144-155. DOI: 10.15809/ irriga.2007v12n2p144-155

GERTH, W. J., J. LI \& G. R. GIANNICO. 2017. Agricultural land use and macroinvertebrate assemblages in lowland temporary streams of the Willamette Valley, Oregon, USA. Agriculture, Ecosystems e Environment, 236: 154-165. DOI: 10.1016/j.agee.2016.11.010

GIBSON, L., T. M. LEE, L. P. KOH, B. W. BROOK, T. A. GARDNER, J. BARLOW, C. A. PERES, C. J. A. BRADSHAW, W. F. LAURANCE, T. E. LOVEJOY \& N. S. SODHI. 2011. Primary forests are irreplaceable for sustaining tropical biodiversity. Nature, 478: 378-381. DOI: 10.1038/nature10425

GIRAUDOUX, P. 2018. Pgirmess: Spatial Analysis and Data Mining for Field Ecologists. https://CRAN.R-project.org/package $=$ pgirmess.

HARDIE, S., C. J. BOBBI. 2018. Compounding effects of agricultural land use and water use in free-flowing rivers: confounding issues for environmental flows. Environmental Management, 61(3):421-431. DOI: 10.1007/s00267017-0836-1

HEPP, L. U. \& S. SANTOS. 2009. Benthic communities of streams related to different land uses in a hydrographic basin in southern Brazil. Environmental Monitoring and Assessment, 157: 305-318. DOI: 10.1007/ s10661-008-0536-7

HEPP, L. U., S. V. MILESI, C. BIASI \& R. M. RESTELLO. 2010. Effects of agricultural and urban impacts on macroinvertebrates assemblages in streams (Rio Grande do Sul, Brazil). Zoologia, 27(1): 106-113. DOI: 10.1590/ S1984-46702010000100016

HEPP, L. U., F. M. URBIM, G. TONELLO, R.
C. LOUREIRO, T. L. SAUSEN, R. FORNEL \& R. M. RESTELLO. 2016. Influence of land-use on structural and functional macroinvertebrate composition communities associated on detritus in Subtropical Atlantic Forest streams. Acta Limnologica Brasiliensia 28: e3. DOI: 10.1590/S2179-975X0616

HORN, H. S. 1966. Measurement of "Overlap" in comparative ecological studies. The American Naturalist, 100 (904): 419-424. DOI: 10. 1086/282436

JUN, Y. C., N. Y. KIM, S. K. KWON, S. C. HAN, I. C. HWANG, J. H. PARK, D. W. WON, M. S. BYUN, H. Y. KONG, J. E. LEE \& S. J. HWANG. 2011. Effects of land use on benthic macroinvertebrate communities: Comparision of two mountain streams in Korea. Annales de Limnologie - International Journal of Limnology, 47: S35-S49. DOI: 10.1051/limn/2011018

JUNQUEIRA, M. V. \& S. C. M. CAMPOS. 1998. Adaptation of the "BMWP" method for water quality evaluation to Rio das Velhas watershed (Minas Gerais, Brazil). Acta Limnologica Brasiliensia, 10(2): 125-135.

KARP, D. S., A. J. ROMINGER, J. ZOOK, J. RANGANATHAN, P. R. EHRLICH \& G. C. DAILY. 2012. Intensive agriculture erodes beta-diversity at large scales. Ecology letters, 15: 963-970. DOI: 10.1111/j.1461-0248. 2012.01815.x

KERANS, B. L. \& J. R. KARR. 1994. A benthic index of biotic integrity (B-IBI) for rivers of Tennessee Valley. Ecological Applications, 4(4): 768-785. DOI: $10.2307 / 1942007$

KINDT, R. \& R. COE. 2005. Tree diversity analysis: A manual and software for common statistical methods for ecological and biodiversity studies. World Agroforestry Centre ICRAF. Nairobi.

KLINK, C. A. \& R. B. MACHADO. 2005. Conservation of the Brazilian Cerrado. Conservaation Biology, 19(13): 707-713. DOI: $10.1111 /$ j.1523-1739.2005.00702.x

KOK, A., E.M. DE OLDE, I. J. M. DE BOER \& R. RIPOLL-BOSCH. 2020. European biodiversity assessments in livestock science: A review of research characteristics and indicators. Ecological Indicators, 112: 1059022 
KÖNIG, R., L. U. HEPP \& S. SANTOS. 2014. Colonisation of low- and high-quality detritus by benthic macroinvertebrates during leaf breakdown in a subtropical stream. Limnologica, 45: 61-68. DOI: 10.1016/j.limno.2013. 11.001

LESLIE A. W. \& W. O. LAMP. 2017. Taxonomic and functional group composition of macroinvertebrate assemblages in agricultural drainage ditches. Hydrobiologia, 787: 99-110. DOI: $10.1007 / \mathrm{s} 10750-016-2947-8$

MARTÍNEZ-SANZ, C., F. GARCÍA-CRIADO, C. FERNÁNDEZ-ALÁEZ, \& M. FERNÁNDEZ-ALÁEZ. 2010. Assessment of richness estimation methods on macroinvertebrate communities of mountain ponds in Castilla y León (Spain). Annales de. Limnologie, 46(2): 101-11. DOI: 10.1051/limn/2010008

MCKINNEY, M. L. \& J. L. LOCKWOOD. 1999. Biotic homogenization: A few winners replacing many losers in the next mass extinction. Trends in Ecology e Evolution, 14(11): 450-453. DOI: 10.1016/S0169-5347(99) $01679-1$

MELO, A. S. 2008. O que ganhamos 'confundindo' riqueza de espécies e equabilidade em um índice de diversidade? Biota Neotropica, 8(3): 21-27. DOI: 10.1590/S1676-06032008000300001

MELO, D. R. 2008. Evolução das Veredas sob Impactos Ambientais nos Geossistemas Planaltos de Buritizeiro/MG. Tese de Doutorado. Universidade Federal de Minas Gerais Federal, Brasil.

MERRITT, R. W. \& K. W. CUMMINS. 1996. An introduction to the aquatic insects of North America. 3rd Ed. Kendall/Hunt. Dubuque. IA. MMA - Ministério do meio Ambiente. O Bioma Cerrado. 2019. https://www.mma.gov.br/ biomas/cerrado. Acessed 09 Oct 2019.

MORAES, P. P. F. 2010. Análise geoquímica-ambiental dos solos de Veredas da Bacia do Rio do Formoso, município de Buritizeiro, Minas Gerais, Brasil. Dissertação de Mestrado. Universidade Federal de Minas Gerais, Brasil.

MUGNAI, R., J. L. NESSIMIAN \& D. F. BAPTISTA. 2010. Manual de identificação de macroinvertebrados aquáticos do Estado do Rio de Janeiro. Tecnical books Editora. Rio de Janeiro. Brasil.

MYERS, N., R. A. MITTERMEIER, C. G. MITTERMEIER, G. A. B. FONSECA \& J. KENT. 2000. Biodiversity hotspots for conservation priorities. Nature, 403: 853-858. DOI: $10.1038 / 35002501$

NAIMAN, R. J. \& H. DÉCAMPS. 1997. The ecology of interfaces: Riparian zones. Annual Review Ecological System, 28(1): 621-658. DOI: 10.1146/annurev.ecolsys.28.1.621

NEWBOLD, T., L. N. HUDSON, S. L. L. HILL, S. CONTU, I. LYSENKO, R. A. SENIOR, L. BÖRGER, D. J. BENNETT, A. CHOIMES, B. COLLEN, J. DAY, A. DE PALMA, S. DÍAZ, S. ECHEVERRIA-LONDOÑO, M. J. EDGAR, A. FELDMAN, M. GARON, M. L. K. HARRISON, T. ALHUSSEINI, D. J. INGRAM, Y. ITESCU, J. KATTGE, V. KEMP, L. KIRKPATRICK, M. KLEYER, Y. PAN, H. R. P. PHILLIPS, D. W. PURVES, A. ROBINSON, J. SIMPSON, S. L. TUCK, E. WEIHER, H. J. WHITE, R. M. EWERS, G. M. MACE, J. P. W. SCHARLEMANN \& A. PURVIS. 2015. Global effects of land use on local terrestrial biodiversity. Nature, 520: 45-50. DOI: $10.1038 /$ nature 14324

NOGUEIRA, D. S., H. S. R. CABETTE \& L. JUEN. 2011. Estrutura e composição da comunidade de Trichoptera (Insecta) de rios e áreas alagadas da bacia do rio Suiá-Miçú, Mato Grosso, Brasil. Iheringia, Série Zoologia, 101(3): 173-180. DOI: 10.1590/S007347212011000200004

OKSANEN, J., F. G. BLANCHET, R. KINDT, P. LEGENDRE, P. R. MINCHIN, R. B. O'HARA, G. L. SIMPSON, P. SOLYMOS, M. H. H. STEVENS \& H. H. WAGNER. 2013. Vegan: Community Ecology Package, Version 2.0-8. http://CRAN.R-project.org/ package $=$ vegan. Acessed 26 Aug 2018.

OLDEN, J. D. \& T. P. ROONEY. 2006. On defining and quantifying biotic homogenization. Global Ecology and Biogeography, 15: 113-120. DOI: 10.1111/j.1466-822X.2006. 00214.x

OLIVEIRA-JUNIOR, J. M. B., P. D. M. JUNIOR, K. DIAS-SILVA, R. P. LEITÃO, C. G. LEAL, P. S. POMPEU, T. A. GARDNER, R. M. HUGHES \& L. JUEN. 2017. Effects of 
human disturbance and riparian conditions on Odonata (Insecta) assemblages in eastern Amazon basin streams. Limnologica Ecology and Management of Inland Waters, 66: 31-39. PATANG, F., A. SOEGIANTO \& S. HARIYANTO. 2018. Benthic macroinvertebrates diversity as bioindicator of water quality of some rivers in East Kalimantan, Indonesia. International Journal of Ecology, 2018: 1-11. R CORE TEAM. 2016. R: A Language and Environment for Statistical Computing. R Foundation for Statistical Computing. Vienna. Austria.

SCHNEIDER, M. O. 1996. Bacia do rio Uberabinha: Uso agrícola do solo e meio ambiente. Tese de Doutorado. Universidade de São Paulo, Brasil.

SHORTLE, J. S., D. G. ABLER \& M. RIBAUDO. 2001. Agriculture and water quality: The issues. In: Environmental policies for agricultural pollution control. J. S. Shortle \& D.G. Abler (ed): 1-18. CABI Publishing, London, UK.

SIEGLOCH, A. E., M. SURIANO, M. SPIES \& A. FONSECA-GESSNER. 2014. Effect of land use on mayfly assemblages structure in Neotropical headwater streams. Anais da Academia Brasileira de Ciências, 86(4): 1735-1747. DOI: 10.1590/00013765201420130516

SILLA, A. J. 2005. Effect of cattle grazing on benthic macroinvertebrate communities in the Kalgan river system, south-west western Australia. BSc (Honours) Thesis. University of Western Australia, Australia.

SWEENEY B. W. 1993. Effects of streamside vegetation on macroinvertebrate communities of White Clay Creek in eastern North America. Proceedings of the Academy of Natural Sciences of Philadelphia, 291-340

TOWNSEND, C., C. ARBUCKLE, T. CROWL $\&$ M. SCARSBROOK. 2003. The relationship between land use and physicochemistry, food resources and macroinvertebrate communities in tributaries of the Taieri River, New Zealand: A hierarchically scaled approach. Freshwater Biology, 37(1): 177-191. DOI: $10.1046 / \mathrm{j} .1365-2427.1997$. 00151.x
TRIVINHO-STRIXINO, S. \& G. STRIXINO. 1995. Larvas de Chironomidae (Diptera) do Estado de São Paulo: Guia de identificação e diagnose dos gêneros. PPG-ERN - UFSCar. São Carlos. Brasil.

UWADIAE，R. E. 2010. Macroinvertebrates functional feeding groups as indices of biological assessment in a tropical aquatic ecosystem: implications for ecosystem functions. New York Science Journal, 3(8): 6-15.

VELLEND, M., K. VERHEYEN, K. M. FLINN, H. JACQUEMYN, A. COLBY, H. VAN CALSTER, G. PETERKEN, B. J. GRAAE, J. BELLEMARE, O. HONNAY, J. BRUNET, M. WULF, F. GERHARDT \& M. HERMY. 2007. Homogenization of forest plant communities and weakening of species-environment relationships via agricultural land use. Journal of Ecology, 95(3): 565-573. DOI: 10.1111/j.1365-2745.2007.01233.x

VIRBICKAS, T., V. PLIÜRAITĖ \& V. KESMINAS. 2011. Impact of agricultural land use on macroinvertebrate fauna in Lithuania. Polish Journal of Environmental Studies, 20(5), 1327-1334.

WHILES, M. R. \& J. B. WALLACE. 1997. Leaf litter decomposition and macroinvertebrate communities in headwater streams draining pine and hardwood catchmants. Hydrobiologia, 353(1-3): 107-119. DOI: 10.1023/A: 1003054827248

WHITTAKER, R. H. 1972. Evolution and the measurement of species diversity. Taxon, 21(2/3): 213-251. DOI: $10.2307 / 1218190$

WOODCOCK, T. S. \& A. HURYN. 2007. The response of macroinvertebrate production to a pollution gradient in a headwater stream. Freshwater Biology, 52(1), 77-196. DOI: 10.1111/j.1365-2427.2006.01676.x

ZHANG, Y., CHENG, L., LI, K., ZHANG, L., CAI, Y., WANG, X. \& J. HEINO. 2019. Nutrient enrichment homogenizes taxonomic and functional diversity of benthic macroinvertebrate assemblages in shallow lakes. Association for the Sciences of Limnology and Oceanography, 64(3): 1047-1058. DOI: 10. 1002/lno.11096

YIRIGUI, Y. , S. W. LEE, A. P. NEJADHASHEMI, M. R. HERMAN \& J. 
W. LEE. 2019. Relationships between riparian forest fragmentation and biological indicators of streams. Sustainability, 11(10): 2879. DOI: $10.3390 /$ su 11102870

ZAMORA-MUÑOZ, C. \& J. ALBA-TERCE-
DOR. 1996. Bioassessment of organically polluted Spanish rivers, using a biotic index and multivariate methods. Journal of the North American Benthological Society, 15(3): 332-352. DOI: 10.2307/1467281 